\title{
The adequacy of artificial oviposition substrates for laboratory rearing of Piezodorus guildinii (Westwood) (Heteroptera, Pentatomidae)
}

\author{
Flávia A.C. Silva ${ }^{1} \&$ Antônio R. Panizzi²
}

${ }^{1}$ Departamento de Zoologia, Universidade Federal do Paraná, Caixa postal 19020, 81531-990 Curitiba-PR. fcloclet@cnpso.embrapa.br ${ }^{2}$ Laboratório de Bioecologia de Percevejos, Embrapa Soja, Caixa postal 231, 86001-970 Londrina-PR. panizzi@cnpso.embrapa.br

\begin{abstract}
The adequacy of artificial oviposition substrates for laboratory rearing of Piezodorus guildinii (Westwood) (Heteroptera, Pentatomidae). Studies in the laboratory tested the suitability of synthetic wool string, cotton string, cheesecloth, and commercial cotton ball as artificial oviposition substrates for the small green stink bug, Piezodorus guildinii (Westwood) (Heteroptera, Pentatomidae). In confined cages, 54\% of total egg masses was laid on synthetic wool string, $31 \%$ on cotton string, and only $15 \%$ on cheesecloth. In an additional test, the best substrate selected, synthetic wool string, received $92 \%$ of egg masses compared to $8 \%$ on the commonly used substrate, cotton ball. Synthetic wool string received the most egg masses of any size, in particular those in the range 11-20 eggs/mass. Because the eggs of $P$. guildinii are laid in two parallel double rows, the egg masses fit the wool string perfectly.

KEYWORDS. Egg deposition; Insecta; insect rearing.

RESUMO. Adequação de substratos artificiais para oviposição nas criações de Piezodorus guildinii (Westwood) (Heteroptera, Pentatomidae). Estudos foram conduzidos em laboratório para testar a adequabilidade de cordão de lã artificial, cordão de algodão, tecido voil e bola de algodão comercial como substrato artificial para oviposição do percevejo verde pequeno, Piezodorus guildinii (Westwood) (Heteroptera, Pentatomidae). Em gaiolas confinadas, 54\% do total de massas de ovos foi depositado sobre o cordão de lã artificial, $31 \%$ sobre o cordão de algodão e apenas $15 \%$ sobre o tecido voil. Em teste adicional, o melhor substato selecionado, cordão de lã artificial, recebeu $92 \%$ das massas de ovos, comparado com $8 \%$ das massas depositadas sobre o substrato comumente utilizado, bola de algodão. O cordão de lã artificial recebeu o maior número de massas de ovos de qualquer tamanho, em particular aquelas com 11-20 ovos/postura. A disposição das massas de ovos de P. guildinii, com os ovos depositados em duas filas paralelas, se encaixou perfeitamente no cordão de lã sintética.
\end{abstract}

PALAVRAS-CHAVE. Criação de insetos; deposição de ovos; Insecta.

The small green stink bug, Piezodorus guildinii (Westwood) (Heteroptera, Pentatomidae), is an important pest of several legume crops in the neotropics (Panizzi et al. 2000). More recently, this insect has increased its abundance in other areas where it used to occur in low numbers, such as in the southeast USA (M. Baur, personal communication, Louisiana State University). Because of the insect's growing importance, maintenance of laboratory colonies of $P$. guildinii to provide healthy insects available for use in bioassays is becoming mandatory.

Several species of phytophagous pentatomids such as the common southern green stink bug, Nezara viridula (L.) are reared in confinement using netted cages or plastic containers under controlled conditions of light, temperature, and relative humidity, and are provided with combinations of natural diets (e.g., Harris \& Todd 1981; Corrêa-Ferreira \& Panizzi 1999, Vandekerkhove \& De Clercq 2004). In addition to the food, suitable substrate for egg laying must be provided, such as paper towels (Shearer \& Jones 1996), draped strips of cheesecloth (Bundy \& McPherson 2000), stretched cheesecloth treated with soybean plant extract (Panizzi et al. 2004), or commercial cotton balls (Silva \& Panizzi 2007).
For species of pentatomids that lay egg masses on double rows in a chain, such as $P$. guildinii, longitudinal structures seems to be more suitable to accommodate the egg mass than flat wide surfaces (ARP, personal observation). Therefore, we decided to test the suitability of different artificial substrates bearing those traits, such as synthetic wool and cotton strings. These potential oviposition substrates were compared to other substrates already tested for pentatomids, such as cheesecloth (Panizzi et al. 2004) and commercial cotton balls (Silva \& Panizzi 2007).

\section{MATERIALAND METHODS}

Insect Colony. During February-March 2007, adults of $P$. guildinii were collected at the Embrapa (Empresa Brasileira de Pesquisa Agropecuária) Farm in Londrina Co., northern Paraná State, from soybean [Glycine max (L.) Merrill] fields. They were taken to the laboratory and pairs $(n=20)$ were placed in each of four clear plastic box $(25 \times 20 \times 20 \mathrm{~cm})$, and provided with pods of green beans, Phaseolus vulgaris L., raw shelled peanuts, Arachis hypogaea L., and fruits (berries) of privet, Ligustrum lucidum Ait. (Oleaceae). Fruits of privet are known 
to increase the fecundity of pentatomids (Panizzi et al. 1996; Panizzi \& Mourão 1999; Coombs 2004). Boxes were kept in an environmental chamber maintained at $25 \pm 1{ }^{\circ} \mathrm{C}$ and $65 \pm 5 \%$ RH and with a photoperiod of 16:08 (L:D). Food was replaced every other day and nymphs obtained were raised to adults.

Oviposition on Synthetic Wool String, on Cotton String, and on Cheesecloth. Ten pairs of $P$. guildinii were selected from the established laboratory colony and placed in each of four netted cages $(30 \times 30 \times 30 \mathrm{~cm})$ used. Foods were provided as described above. On the inside top of each cage were hung a synthetic wool string (Famíliaß, São Paulo,SP, Brazil) $(30 \mathrm{~cm}$ long x $0.3 \mathrm{~cm}$ diameter), a cotton string (Têxtil São João Ltda., São João da Boa Vista, RS, Brazil) ( $30 \mathrm{~cm}$ long x $0.2 \mathrm{~cm}$ diameter), and a cheesecloth strip (Têxtil São João Ltda., São João da Boa Vista, RS, Brazil) ( $30 \mathrm{~cm}$ long x $2 \mathrm{~cm}$ width); these were attached to the top of the cage with sticky tape. These structures were placed $15 \mathrm{~cm}$ apart from each other.

Cages were checked daily, and the number of egg masses and eggs/mass deposited on each substrate was recorded and egg masses removed. This procedure was carried out for six consecutive days, for a total of 24 observations (6 days x 4 cages). The mean numbers and mean percentages of egg masses and of eggs/mass were calculated for each substrate; the size of egg masses was ranked from 1-10, 11-20, 21-30, and $>30$ eggs/mass.

Oviposition on Synthetic Wool String and on Cotton Ball. Ten pairs of $P$. guildinii were selected from the established laboratory colony and placed in each of four netted cages (30 x $30 \times 30 \mathrm{~cm}$ ) used. Bugs were fed as described. On the inside top of each cage were hung a synthetic wool string $(30 \mathrm{~cm}$ long $\mathrm{x} 0.3 \mathrm{~cm}$ diameter) and a commercial absorbent cotton (Cremer S.A., Blumenau, SC, Brazil) ball ( $0.5 \mathrm{~cm}$ diameter).

Cages were checked daily, and the number of egg masses and eggs/mass deposited on each substrate was recorded and removed as above. This procedure was carried out for six

Table I. Total mean $( \pm$ SE) and mean $( \pm$ SE) percentage number of egg masses and eggs laid by Piezodorus guildinii on artificial substrates in the laboratory $(\mathrm{n}=24)$.

\begin{tabular}{|c|c|c|c|c|c|}
\hline \multirow{2}{*}{ Substrate } & \multicolumn{4}{|c|}{ Mean number $( \pm S E M)^{l}$} & \multirow{2}{*}{$\begin{array}{c}\text { Mean } \\
( \pm \text { SEM }) \\
\text { eggs/mass }\end{array}$} \\
\hline & $\begin{array}{l}\text { Egg } \\
\text { mass }\end{array}$ & $\begin{array}{l}\text { Egg mass } \\
(\%)^{2}\end{array}$ & Egg & $\begin{array}{l}\text { Egg } \\
(\%)^{2}\end{array}$ & \\
\hline $\begin{array}{l}\text { Synthetic } \\
\text { wool string }\end{array}$ & $\begin{array}{c}3.8 \mathrm{a} \\
( \pm 0.58)\end{array}$ & $\begin{array}{c}53,8 \mathrm{a} \\
( \pm 0.33)\end{array}$ & $\begin{array}{c}71.4 \mathrm{a} \\
( \pm 9.90)\end{array}$ & $\begin{array}{c}54,4 \mathrm{a} \\
( \pm 0.31)\end{array}$ & $\begin{array}{c}17.9 a \\
( \pm 1.60)\end{array}$ \\
\hline Cotton string & $\begin{array}{c}2.2 \mathrm{ab} \\
( \pm 0.45)\end{array}$ & $\begin{array}{c}31,0 \mathrm{~b} \\
( \pm 0.26)\end{array}$ & $\begin{array}{l}41.6 \mathrm{ab} \\
( \pm 9.11)\end{array}$ & $\begin{array}{c}31,7 \mathrm{~b} \\
( \pm 0.29)\end{array}$ & $\begin{array}{l}15.5 \mathrm{ab} \\
( \pm 2.32)\end{array}$ \\
\hline Cheesecloth & $\begin{array}{c}1.1 \mathrm{~b} \\
( \pm 0.29)\end{array}$ & $\begin{array}{c}15,2 \mathrm{~b} \\
( \pm 0.17)\end{array}$ & $\begin{array}{c}18.3 \mathrm{~b} \\
( \pm 4.98)\end{array}$ & $\begin{array}{c}13,9 \mathrm{~b} \\
( \pm 0.16)\end{array}$ & $\begin{array}{c}9.7 \mathrm{~b} \\
( \pm 2.12)\end{array}$ \\
\hline
\end{tabular}

${ }^{1}$ Means in each column followed by the same letter are not significantly different $(\mathrm{P}=0.05$; Tukey test).

${ }^{2}$ Percentage data were transformed to arcsine $\sqrt{ }(x+1)$ before the statistical comparison. consecutive days, for a total of 24 observations (6 days x 4 cages). The mean numbers and mean percentages of egg masses and of eggs/mass were calculated on each substrate; the size of egg masses was ranked from 1-10, 11-20, and 21-30 eggs/mass.

Data are presented as mean numbers and as mean percentages because percentages give a better idea of the bugs' preferences for an oviposition substrate, and the actual numbers inform the reader upon which numbers the percentages were calculated.

Statistics. Total mean number and percentages of egg masses and eggs/mass laid on each substrate were calculated and submitted to the analysis of variance (ANOVA). Mean numbers and mean percentages, the latter transformed using arcsine before comparison, were compared using the Tukey test. These analyses were made using the statistic program SAS 8.2. (SAS Institute 1981; Zar 1984).

\section{RESULTS ANDDISCUSSION}

Oviposition on Synthetic Wool String, on Cotton String, and on Cheesecloth. The total mean number of egg masses laid was significantly greater on strings, either synthetic wool or cotton, than on cheesecloth (Table I). More than 50\% of egg masses were laid on the synthetic wool string, $31 \%$ on cotton string, and $15 \%$ on cheesecloth. The total mean number of eggs was greater on the wool string than on cheesecloth. A significantly greater total mean percentage of eggs was laid on the wool string than on the two other substrates. Mean number of eggs/mass was greater on the wool string than on the cheesecloth, with intermediate value on the cotton string (Table I).

P. guildinii has been observed to lay eggs in two parallel rows on strings hung in the rearing containers. The Asian species, Piezodorus hybneri Gmelin also deposits eggs in two parallel rows, and hemp strings are commonly used as

Table II. Total mean $( \pm$ SE) and mean $( \pm$ SE) percentage number of egg masses and eggs laid on artificial substrates by Piezodorus guildinii in the laboratory $(n=24)$.

\begin{tabular}{|c|c|c|c|c|c|}
\hline \multirow{2}{*}{ Substrate } & \multicolumn{4}{|c|}{ Mean number $( \pm S E M)^{l}$} & \multirow{2}{*}{$\begin{array}{c}\text { Mean } \\
( \pm \text { SEM }) \\
\text { eggs/mass }^{1}\end{array}$} \\
\hline & $\begin{array}{l}\text { Egg } \\
\text { mass }\end{array}$ & $\begin{array}{l}\text { Egg mass } \\
(\%)^{2}\end{array}$ & Egg & $\begin{array}{l}\text { Egg } \\
(\%)^{2}\end{array}$ & \\
\hline $\begin{array}{l}\text { Synthetic } \\
\text { wool string }\end{array}$ & $\begin{array}{c}5.5 \mathrm{a} \\
( \pm 2.65)\end{array}$ & $\begin{array}{c}92.3 \mathrm{a} \\
( \pm 1.90)\end{array}$ & $\begin{array}{c}33.2 \mathrm{a} \\
( \pm 4.61)\end{array}$ & $\begin{array}{c}82.9 \mathrm{a} \\
( \pm 0.50)\end{array}$ & $\begin{array}{c}18.0 \mathrm{a} \\
( \pm 2.11)\end{array}$ \\
\hline $\begin{array}{l}\text { Commercial } \\
\text { cotton ball }^{4}\end{array}$ & $\begin{array}{c}0.5 \mathrm{~b} \\
( \pm 0.15)\end{array}$ & $\begin{array}{c}7,7 \mathrm{~b} \\
( \pm 0.10)\end{array}$ & $\begin{array}{c}6.8 \mathrm{~b} \\
( \pm 2.40)\end{array}$ & $\begin{array}{c}17.1 \mathrm{~b} \\
( \pm 0.30)\end{array}$ & $\begin{array}{c}6.0 \mathrm{~b} \\
( \pm 1.93)\end{array}$ \\
\hline
\end{tabular}

${ }^{1}$ Means in each column followed by the same letter are not significantly different $(\mathrm{P}=0.05$; Tukey test $)$.

${ }^{2}$ Percentage data were transformed to arcsine $\sqrt{ }(x+1)$ before the statistical comparison.

${ }^{3}$ Best artificial oviposition substrate selected from the previous test.

${ }^{4}$ Commonly used oviposition substrate for other species of pentatomids. 

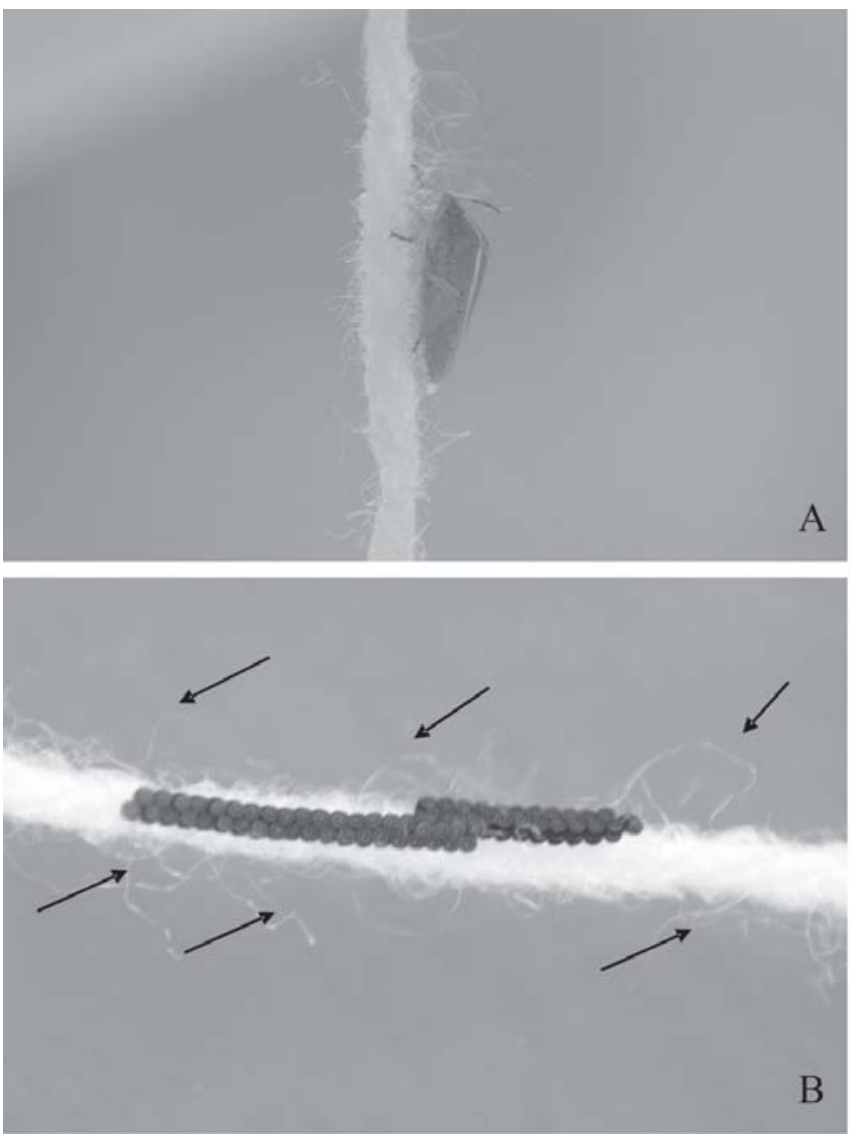

Fig. 1. Piezodorus guildinii female in pre-oviposition position on synthetic wool string (A); egg masses deposited on wool strings (B). Note the fibers emerging from the string (indicated by arrows) that may stimulate mechanoreceptors on the genital plaques.

oviposition sites (Higuchi 1994a). In nature, both species prefer to lay eggs on elongated structures, e.g., soybean pods rather than the broader soybean leaflet (Panizzi \& Smith 1977; Higuchi 1994b). The fact that $P$. guildinii females preferred the synthetic wool string (Fig. 1A) over the cotton string may be related to the loose fibers present on the former (Figs. 1A, 1B), which may stimulate hairs (possibly mechanoreceptors sensilla) on the genital plaques. This suspicion is reinforced by the reported behavior that ovipositing females of $N$. viridula gently touch the abdomen to the substrate, probably stimulating the mechanoreceptors, before expelling the eggs (Panizzi 2006). This mechanism of fibers stimulating mechanoreceptors, although not fully demonstrated, is believed to be an important reason why several species of pentatomids do prefer to oviposit on commercial cotton balls (Silva \& Panizzi 2007).

For all categories of egg mass size, the total mean number (Fig. 2A) and total mean percentages (Fig. 2B) indicated that most egg masses were deposited on the wool string, followed by cotton string and cheesecloth. This difference was particularly marked for egg masses falling in the 11 to 20 eggs/ mass category. This range includes the egg mass size usually laid in nature by female P. guildinii, i.e., 14 eggs (Panizzi \& Smith 1977).

Oviposition on Synthetic Wool String and on Cotton Ball. Because the previous test indicated that the synthetic wool string yielded the best results, this substrate was compared to commercial cotton ball. This substrate accommodates $\approx 80 \%$ of $P$. guildinii egg masses in laboratory bioassays (Silva \& Panizzi 2007). The present results indicate that 10X more egg masses were laid on the wool string than on the cotton ball (Table II); over $90 \%$ of egg masses and over $80 \%$ of eggs were deposited on the first than on the second substrate. In addition, the number of eggs/mass was significantly greater in masses laid on the wool strings than on the cotton balls (Table II).

As was observed in the first test, the total mean number (Fig. 3A) and total mean percentages (Fig. 3B) of egg masses of all sizes were significantly greater on the wool string than on the cotton ball, except for those masses with more eggs (21-30 eggs). These results testing dual choices further indicate that $P$. guildinii females prefer the elongated substrate (wool string) over the broader cotton ball.

In conclusion, these laboratory tests demonstrate the suitability of synthetic wool string as an oviposition substrate for $P$. guildinii. Although strings are routinely used to receive
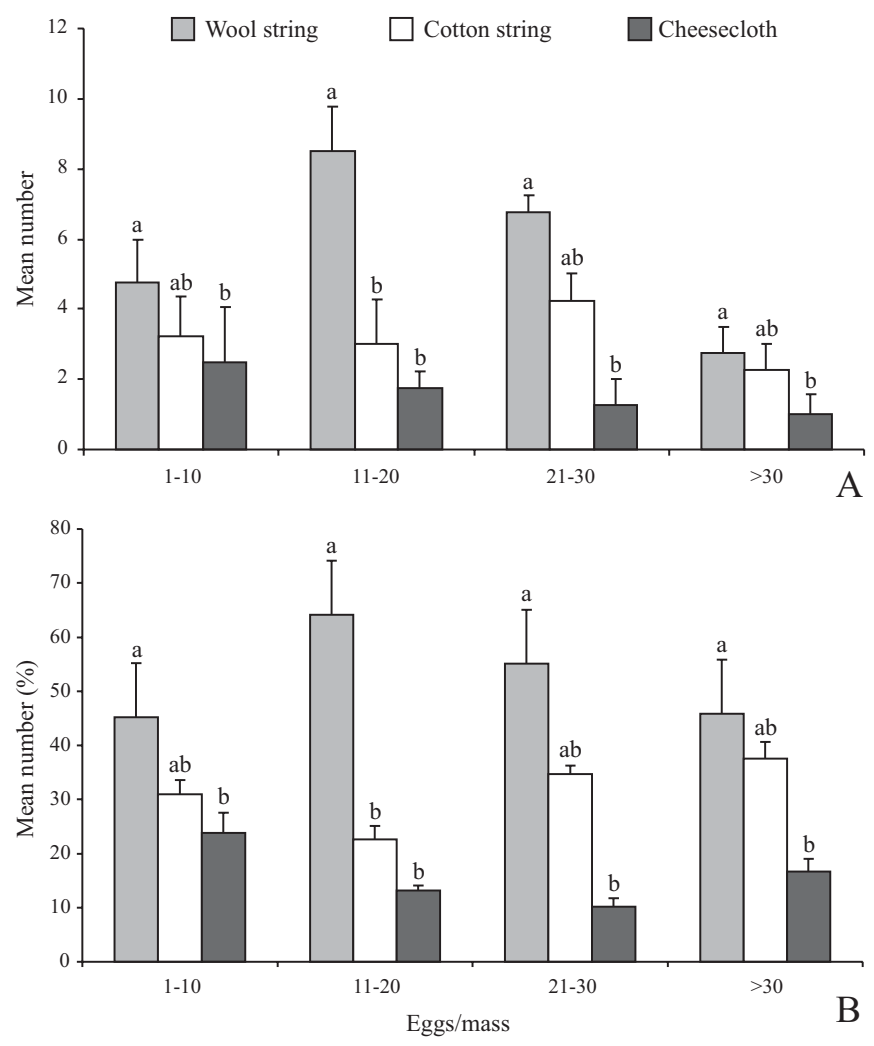

Fig. 2. Total mean $( \pm$ SE) and mean $( \pm$ SE) percentage number of egg masses and eggs laid by Piezodorus guildinii on artificial substrates in the laboratory $(\mathrm{n}=24)$, ranked by the different classes (egg mass size). Means followed by the same letter are not significantly different $(\mathrm{P}=$ 0.05; Tukey test). Percentage data were transformed to arcsine $\sqrt{ }(\mathrm{x}+$ 1) before the statistical comparison. 

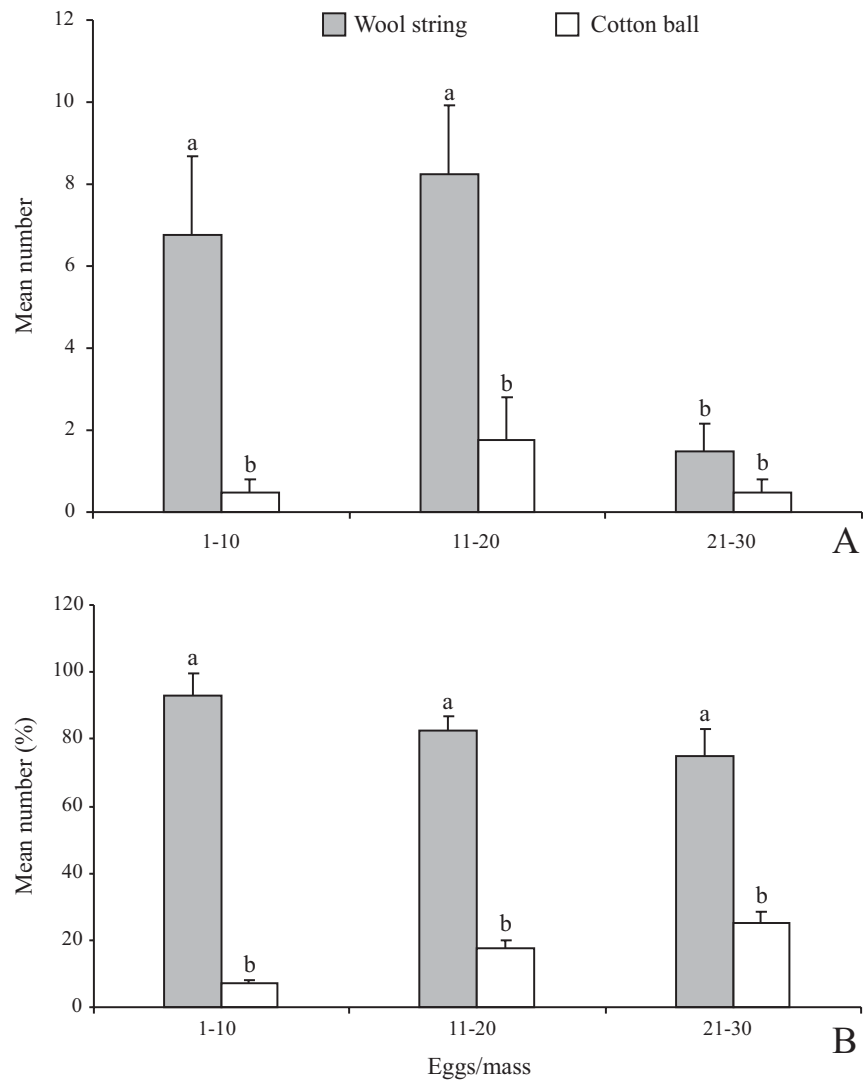

Fig. 3. Total mean $( \pm \mathrm{SE})$ and mean $( \pm \mathrm{SE})$ percentage number of egg masses and eggs laid by Piezodorus guildinii on artificial substrates in the laboratory $(\mathrm{n}=24)$, ranked by the different classes (egg mass size). Synthetic wool string was the best artificial oviposition substrate selected from the previous test. Commercial cotton balls are a commonly used oviposition substrate for other species of pentatomids. Means followed by the same letter are not significantly different $(P=0.05$; Tukey test). Percentage data were transformed to arcsine $V(x+1)$ before the statistical comparison.

eggs of $P$. guildinii (ARP, unpublished) and P. hybneri (Higuchi 1994a), strings bearing fibers yield better results and should be preferably used.

Acknowledgments. We thank Carl W. Schaefer and Flávio Moscardi for critically reading the manuscript. This study was sponsored by the Empresa Brasileira de Pesquisa Agropecuária (Embrapa). FACS was supported by a scholarship granted by the Conselho Nacional de Desenvolvimento Científico e Tecnológico (CNPq). This paper was approved for publication by the Editorial Board of Embrapa Soja as manuscript number 16/2007.

\section{REFERENCES}

Bundy, C. S. \& R. M. McPherson. 2000. Morphological examination of stink bug (Heteroptera: Pentatomidae) eggs on cotton and soybeans, with a key to genera. Annals of the Entomological Society of America 93: 616-624.

Coombs, M. 2004. Broadleaf privet, Ligustrum lucidum Aiton (Oleaceae), a late-season host for Nezara viridula (L.), Plautia affinis Dallas and Glaucias amyoti (Dallas) (Hemiptera: Pentatomidae) in northern New South Wales, Australia. Australian Journal of Entomology 43: 335-339.

Corrêa-Ferreira, B. S. \& A. R. Panizzi. 1999. Percevejos da soja e seu manejo. Embrapa Soja Circular Técnica 24: 1-45.

Harris, V. E. \& J. W. Todd. 1981. Rearing the southern green stink bug, Nezara viridula, with relevant aspects of its biology. Journal of the Georgia Entomological Society 16: 203-210.

Higuchi, H. 1994a. Photoperiodic induction of diapause, hibernation and voltinism in Piezodorus hybneri (Heteroptera: Pentatomidae). Applied Entomology and Zoology 29: 585-592.

Higuchi, H. 1994b. Seasonal prevalence and mortality factors of eggs of Piezodorus hybneri Gmelin (Heteroptera: Pentatomidae) in a soybean field. Japanese Journal of Applied Entomology and Zoology 38: 17-21.

Panizzi, A. R. 2006. Possible egg positioning and gluing behavior by ovipositing southern green stink bug, Nezara viridula (L.) (Heteroptera: Pentatomidae). Neotropical Entomology 35: 149151.

Panizzi, A. R.; M. Berhow \& R. J. Bartelt. 2004. Artificial substrate bioassay for testing oviposition of southern green stink bug conditioned by soybean plant chemical extracts. Environmental Entomology 33: 1217-1222.

Panizzi, A. R.; J. E. McPherson; D. G. James; M. Javahery \& R. M. McPherson. 2000. Stink bugs (Pentatomidae), pp. 421-474. In: C. W. Schaefer \& A. R. Panizzi (eds.), Heteroptera of Economic Importance. CRC Press, Boca Raton, FL, USA.

Panizzi, A. R. \& A. P. M. Mourão. 1999. Mating, ovipositional rhythm and fecundity of Nezara viridula (L.) (Heteroptera: Pentatomidae) fed on privet, Ligustrum lucidum Thunb., and on soybean, Glycine $\max ($ L.) Merrill fruits. Anais da Sociedade Entomológica do Brasil 28: 35-40.

Panizzi, A. R. \& J. G. Smith. 1977. Biology of Piezodorus guildinii: Oviposition, development time, adult sex ratio and longevity. Annals of the Entomological Society of America 70: 35-39.

Panizzi, A. R.; L. M. Vivan; B. S. Corrêa-Ferreira \& L. A. Foerster. 1996. Performance of southern green stink bug (Heteroptera: Pentatomidae) nymphs and adults on a novel food plant (Japanese privet) and other hosts. Annals of the Entomological Society of America 89: 822-827.

SAS Institute. 1981. SAS for linear models. A guide to the ANOVA and GLM procedures. SAS Institute, Cary, N. C.

Shearer, P. W. \& V. P. Jones. 1996. Suitability of macadamia nut as a host plant of Nezara viridula (Hemiptera: Pentatomidae). Journal of Economic Entomology 89: 996-1003.

Silva, F. A. C. \& A. R. Panizzi. 2007. Cotton balls as an oviposition substrate for laboratory rearing of phytophagous stink bugs (Heteroptera: Pentatomidae). Annals of the Entomological Society of America 100: 745-748.

Vandekerkhove, B. \& P. De Clercq. 2004. Effects of an encapsulated formulation of lambda-cyhalothrin on Nezara viridula and its predator Podisus maculiventris (Heteroptera: Pentatomidae). Florida Entomologist 87: 112-118.

Zar, J. H. 1984. Biostatistical analysis, 2nd ed., Prentice-Hall, Englewood Cliffs, N. J.

Received 13/07/2007; accepted 29/01/2008 